\title{
Reduction of Dust in the Longwall Faces of Coal Mines: Problems and Perspective Solutions
}

\author{
Anton V. KORNEV ${ }^{1 *}$, Gennady I. KORSHUNOV ${ }^{2}$ and Dušan KUDELAS ${ }^{3}$
}

Authors' affiliations and addresses: ${ }^{1}$ Industrial Safety Department, Saint-Petersburg Mining University, 21 linia V.O., 2, SaintPetersburg, Russia

e-mail: Kornev_AV@ pers.spmi.ru

${ }^{2}$ Industrial Safety Department, Saint-Petersburg Mining University,21 linia V.O., 2, Saint-

Petersburg, Russia

e-mail: KorshunovGI@pers.spmi.ru

${ }^{3}$ Institute of Earth Resources, Faculty of Mining, Ecology, Process Control and Geotechnologies Technical University of Kosice, PK 19, 04200 Košice, Slovak Republic

e-mail: dusan.kudelas@tuke.sk

*Correspondence:

Anton V. Kornev, Industrial Safety Department, Saint-Petersburg Mining University, 21 linia

V.O., 2, Saint-Petersburg, Russia

e-mail: Kornev AV@pers.spmi.ru

How to cite this article:

Kornev, A.V., Korshunov, G. I. and Kudelas, D. (2021). Reduction of Dust in the Longwall Faces of Coal Mines: Problems and Perspective

Solutions. Acta Montanistica Slovaca, Volume 26 (1), 84-97

DOI:

https://doi.org/10.46544/AMS.v26i1.07

\begin{abstract}
Despite the increasing reliance on alternative and renewable energy sources in recent years, coal is set to continue being the most vital element of the global energy sector. The world coal supply $(1,070$ billion tons) shall last for 130 years with the current mining levels. In contrast to some large countries (such as the USA and Germany) reducing their coal production and consumption, Russia plans to increase the coal production levels as part of its strategy regarding the future of the coal mining industry. The annual volume of coal output is more than 440 million tons, $1 / 3$ of which is extracted underground. The current and projected levels of underground coal mining present a set of issues pertaining to elevated dust concentration in the air and increased dust dispersion. High dust concentration in the air leads to damage to the skin, mucous membranes and respiratory organs of workers. Also, with high dust content, visibility in the longwalls decreases, the risk of injury and accidents increases.

The present article deals with the formation of detrimental dust conditions that happen in the course of cleaning and preparatory mining operations in coal mines. The article reviews the international practices on dust reduction in coal mining operations and provides an overview of studies on dustiness levels and airborne dust composition in longwall faces of coal mines. It also presents mathematical models dealing with projections on dust composition, including projections on most hazardous dust particles the size of 0.1-10 and 0.1-35 $\mu \mathrm{m}$. The article also presents a newly developed wetting method showing increased effectiveness.
\end{abstract}

\section{Keywords}

Underground coal mining, longwalls, dustiness, pneumoconiosis, aerosol dispersed composition, dust control, forecast of dust conditions, complex dedusting measures, dust wettability. 


\section{Introduction}

The current state of the global energy industry is such that, despite the commitment from the leading countries to decrease carbon emissions, eliminating the reliance on coal does not appear to be a viable option for a number of reasons. Firstly, energy from coal amounts to $27 \%$ of the global energy mix (as of 2019). To give context, natural gas amounts to $24.2 \%$, and alternative energy sources together with nuclear energy and hydroelectric power amount to only $15,7 \%$. Secondly, at current consumption levels, the global coal reserves should last for 132 years, and for some areas - even longer (for NA the estimates put the reserves levels at 367 years, and for CIS countries — at 338 years) (BP Statistical Review of World Energy, 2020).

The main coal deposits are located in four countries, which together account for $65 \%$ of global reserves: the US (23\%), the Russian Federation (15\%), Australia (14\%) and China (13\%). At present, global coal reserves are estimated to contain 1,070 billion tons. Despite some decline in coal consumption in 2019 and a drop in global coal prices, the coal industry remains promising and continues expanding (BP Statistical Review of World Energy, 2020).

When it comes to Russia, coal remains not only a valuable energy source but also one of the country's main exports, which means it contributes greatly to the Russian economy and employment levels. Coal mining and coal processing enterprises account for 160,00 jobs. Russia's yearly coal production level is 440 million tons, one-third of which is mined underground. As per the forecast of socio-economic development of the Russian Federation for the period until 2036, Russia is expected to raise the production levels to 670 million tons a year by 2035 , as well as to expand exports to the Asia-Pacific region (Projections on social and economic development of Russia for the period up to 2036, 2018; Tarazanov and Gubanov, 2020; BP Statistical Review of World Energy, 2020).

The increase in production is achieved via the implementation of highly efficient mining equipment, with feed rates of up to $50 \mathrm{~m} / \mathrm{min}$, increased lengths of longwalls (up to $400 \mathrm{~m}$ ) and extraction columns (up to and exceeding 2,500 m) and improved labour efficiency. With the increased frequency of preparatory mine works and creation of new longwall faces comes a worsening in the dust- and gas-related working conditions, which leads to worsening of occupational health and safety (Gendler and Nguen, 2018; Chemezov, 2019; Magomet et al., 2019; Smirnyakov and Smirnyakova, 2016; Zhikharev et al., 2018).

The goal of the present study is to develop suggestions, recommendations, and practical solutions for dust reduction in the longwall faces of coal mines.

The objectives are as follows:

1. To analyze the international practices on improving dust conditions in coal mines.

2. To study the factors influencing the dustiness and aerosol dispersion composition in the mine faces.

3. To develop suggestions, recommendations, and practical solutions for dust reduction in longwall faces of coal mines.

\section{Analysis of dustiness-related working conditions at coal mines and associated occupational diseases. Defining the problem}

The methods currently employed in Russian coal mines do not lower the time-weighted average (TWA) dust contents to maximum permissible concentration (MPC) or even to levels close to it. The mining works also don't involve particle-size distribution tests, which are vital to assessing the effectiveness of dust reduction methods and the rate of development of occupational respiratory diseases. The most severe diseases of respiratory and cardiovascular systems of the body are caused by the accumulation of not airborne dust per se, but specifically by small dust particles with sizes up to 2.5, 10 and $35 \mu \mathrm{m}$ (Haritonov et al., 2019; Air quality guidelines: global update 2005. Particulate matter, ozone, nitrogen dioxide and sulfur dioxide, 2006; Danilov et al., 2017; Pope et al., 2002; Samoli et al., 2008). In the process of defining the working levels of dust concentration and choosing the wetting method, the mechanical properties and the contents of the coal dust are often ignored, despite the fact that these factors are very wide-ranging. Data on projected dustiness levels are not factored into decisions regarding changes to wetting methods and modes. Sometimes the control of air quality and soundness of wetting and mining equipment is not performed at all. This results in increased dustiness levels, which negatively affect not only the miners' skin, mucous membranes and respiratory organs, but also leads to various occupational diseases, reduces visibility in the face area, and makes the working conditions more hazardous.

Dust reduction is a relevant issue for the mining industry (Danilov et al., 2017; Gendler et al., 2019; Kovshov and Barkan, 2016). The majority of working zones in coal mines are characterized by hazardous dustiness levels of varying severity. For example, at the mines of one of the world's largest Russian coal mining companies, "SUEK, JSC", at 79\% of working areas, the concentration of dust in the air exceeds the MPC. At the same time, $51 \%$ of workplaces can be classified as class $3.1,21 \%$ - as class $3.2,7 \%$ - as class 3.3 (Tab. 1) of hazardous working areas classification. Of those, $51 \%$ of working zones fall under class $3.1,21 \%$ - under class 3.2 , and $7 \%$ - under class 3.3 (Tab. 1). 
The number of occupational diseases caused by exposure to industrial fibrogenic aerosols changes dramatically from one mine to the next (Fig. 1) and, in some cases, reaches $30 \%$ of total occupational diseases (Fig. 2).

Tab. 1. Results of the assessment of working conditions at the company mines from 2015 to 2018

\begin{tabular}{|c|c|c|c|c|c|c|c|c|c|}
\hline \multirow[t]{2}{*}{ Mine № } & \multirow{2}{*}{\multicolumn{2}{|c|}{ Total employees / work spaces }} & \multicolumn{4}{|c|}{$\begin{array}{c}\text { Total employees / work spaces ranged } \\
\text { by working condition class }\end{array}$} & \multicolumn{3}{|c|}{$\begin{array}{l}\text { Total employees / work spaces } \\
\text { ranged by working condition } \\
\text { class (classification by severity } \\
\text { of fibrogenic aerosols) }\end{array}$} \\
\hline & & & 2 & 3.1 & 3.2 & 3.3 & 3.1 & 3.2 & 3.3 \\
\hline \multirow{2}{*}{1} & Work spaces & 591 & 223 & 193 & 165 & 116 & 340 & 36 & 20 \\
\hline & Employees & 1505 & 117 & 357 & 450 & 475 & & & \\
\hline \multirow{2}{*}{2} & Work spaces & 526 & 92 & 163 & 138 & 133 & 154 & 127 & 26 \\
\hline & Employees & 1495 & 189 & 240 & 549 & 517 & & & \\
\hline \multirow{2}{*}{3} & Work spaces & 435 & 67 & 200 & 117 & 51 & 162 & 71 & 16 \\
\hline & Employees & 967 & 141 & 273 & 298 & 255 & & & \\
\hline \multirow{2}{*}{4} & Work spaces & 402 & 93 & 143 & 116 & 50 & 179 & 65 & 23 \\
\hline & Employees & 571 & 126 & 201 & 162 & 82 & & & \\
\hline \multirow{2}{*}{5} & Work spaces & 831 & 156 & 282 & 229 & 164 & 329 & 127 & 31 \\
\hline & Employees & 1797 & 226 & 561 & 577 & 433 & & & \\
\hline \multirow{2}{*}{6} & Work spaces & 354 & 66 & 106 & 93 & 89 & 107 & 153 & 18 \\
\hline & Employees & 827 & 103 & 134 & 281 & 309 & & & \\
\hline \multirow{2}{*}{7} & Work spaces & 225 & 12 & 74 & 52 & 87 & 128 & 10 & 64 \\
\hline & Employees & 470 & 39 & 123 & 127 & 181 & & & \\
\hline \multirow{2}{*}{ TOTAL } & Work spaces & 3364 & 603 & 1161 & 910 & 690 & 1399 & 589 & 198 \\
\hline & Employees & 7632 & 1047 & 1889 & 2444 & 2252 & & & \\
\hline
\end{tabular}

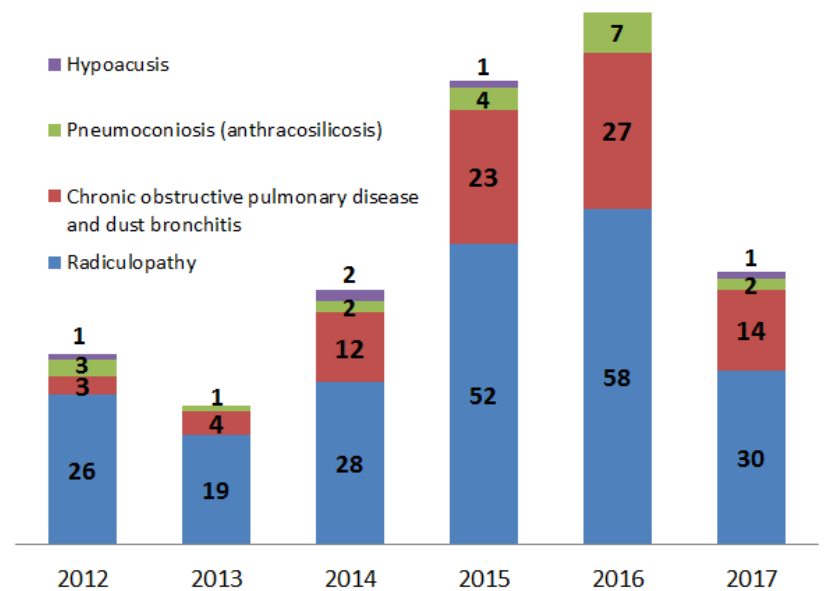

Fig 1. Data on occupational diseases from a mine in Eastern Donbass (Source: Authors) 


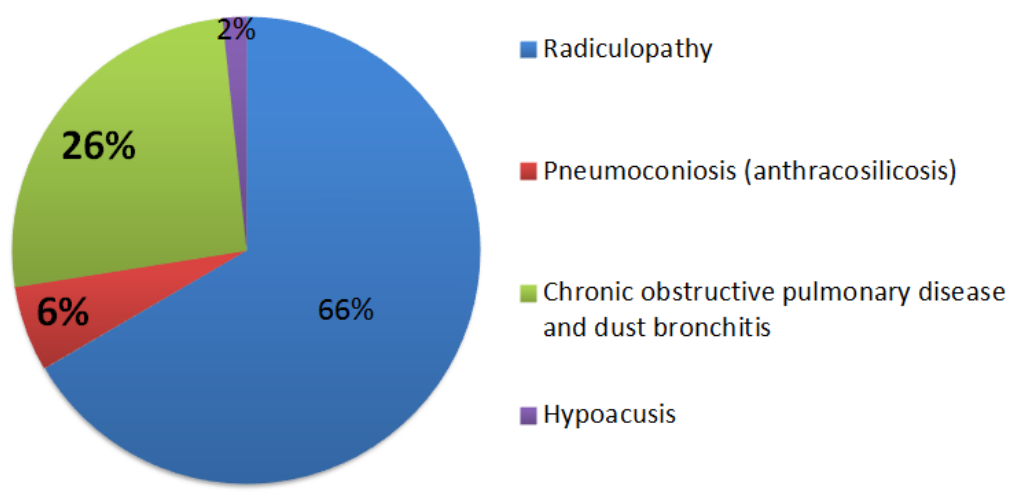

Fig. 2. Occupational diseases at a mine in Eastern Donbass from 2012 to 2017 (Source: Authors)

Anthracosilicosis, dust bronchitis and other respiratory afflictions are more frequent in workers who spend most of their shifts in areas of high dustiness (such as longwall faces): machine operators, miners, wiremen, and overseers (Tab. 2) (Romanchenko et al., 2016; Haritonov et al., 2019; Chebotarjov, 2019; Han et al., 2015).

\begin{tabular}{|c|c|c|c|}
\hline \multirow{3}{*}{ Job title } & \multirow{2}{*}{\multicolumn{3}{|c|}{ Number of diseases reported for the first time }} \\
\hline & & & \\
\hline & Anthracosilicosis & $\begin{array}{l}\text { Chronic obstructive pulmonary } \\
\text { disease and chronic bronchitis }\end{array}$ & Total dust-related diseases \\
\hline Shaft miner & 4 & 10 & 14 \\
\hline Stope miner & 2 & 11 & 13 \\
\hline Overman & 2 & 10 & 12 \\
\hline Underground wireman & 1 & 11 & 12 \\
\hline Shot-firer & 1 & 9 & 10 \\
\hline Underground miner & 0 & 8 & 8 \\
\hline Prospector & 1 & 4 & 5 \\
\hline Overseer & 0 & 4 & 4 \\
\hline Mine captain & 1 & 2 & 3 \\
\hline Hoist operator & 1 & 2 & 3 \\
\hline Explosives' distributor & 0 & 3 & 3 \\
\hline $\begin{array}{c}\text { Operator of rock removing } \\
\text { machines }\end{array}$ & 1 & 1 & 2 \\
\hline Surface wireman & 1 & 1 & 2 \\
\hline Deputy captain & 1 & 1 & 2 \\
\hline Shift manager & 0 & 2 & 2 \\
\hline $\begin{array}{l}\text { Deputy Chief Engineer for } \\
\text { Maintenance }\end{array}$ & 1 & 1 & 2 \\
\hline Bulldozer operator & 1 & 1 & 2 \\
\hline On-duty wireman for repairs & 0 & 1 & 1 \\
\hline $\begin{array}{l}\text { Operator of underground } \\
\text { installations }\end{array}$ & 1 & 0 & 1 \\
\hline Mine undermanager & 0 & 1 & 1 \\
\hline $\begin{array}{l}\text { Service-man for manual } \\
\text { welding }\end{array}$ & 1 & 0 & 1 \\
\hline TOTAL & 20 & 83 & 103 \\
\hline
\end{tabular}

Silicosis and chronic (dust) bronchitis account for almost half (41-47\%) of all occupational respiratory diseases (Projections on social and economic development of Russia for the period up to 2036, 2018).

High occupational morbidity levels caused by dustiness is not a Russia-specific problem. The same can be observed in mines of China, US and Australia. Surveys of 29.5 thousand US miners conducted from 1996 to 2002 showed 886 people with various lengths of service diagnosed with pneumoconiosis. From the 1970-s to the start of the $21^{\text {st }}$ century, almost 70,000 miners died from pneumoconiosis (Colinet et al., 2010). In China, the miners receive tens of billions of dollars yearly for working in hazardous dust-related conditions (Han et al., 2015; Ji et al., 2016; Wang et al., 2016; Xia et al., 2014). 


\section{Overview of dust reduction methods in coal mines}

All technical measures for dust reduction can be divided into several types based on the means, principles, and areas of application. Let us take a look at those that are predominantly used in longwall faces (Federal regulations on industrial safety. Regulations on explosion prevention of dusty gas-air atmospheres in coal mines, 2013; Federal regulations on industrial safety. Instructions on dust control in coal mines, 2019).

The first type includes measures pertaining to reducing the concentration of small airborne dust particles with an input of fresh air. In other words, the dust cloud is hit with an air jet moving at an appropriate speed.

The second type includes measures pertaining to the removal of polluted air via special air control systems (built-in or outgoing) that is followed with the scrubbing of that air using dry or wet filters (CFT GmbH Compact Filter Technic. Consistently high quality. Dry dedusting, wet dedusting, dedusting for dry drilling, 2020).

The third type includes measures pertaining to dust wetting, a process of spraying dust clouds with water through nozzles. This incorporates wetting through nozzles located under shearer blades, a procedure aimed to prevent frictional ignition of coal and methane. In addition to nozzles located under the blades, shearers also have nozzles on their bodies. Modern shearers by Eickhoff and JOY come with nozzles of different sizes that can supply water to the blades at volumes from 0.94 to $4.13 \mathrm{l} / \mathrm{min}$. Total water consumption levels depend on the shearer model. For JOY 7LS shearers, for example, the consumption levels range from 313.3 to 520.0 1/min (Korshunov and Romanchenko, 2016; Romanchenko et al., 2016; Romanchenko et al., 2011).

Sections of the canopy support set-ups of wetting measures where water is sprayed either towards the face to ensure dust suppression or the opposite way (to the gob, under the roof) to reduce dustiness during the sliding of the canopy sections. In such a case, a wetting curtain (water, mist, or fabric filter) is set up in a face-adjacent drift with an upcast air current (20 $\mathrm{m}$ from the roadhead).

The fourth type includes measures pertaining to the pre-emptive pumping of water into the seam (water infusion) to increase saturation and reduce dustiness. This process involves making calculations to determine the optimal number and length of holes that are to be drilled into the seam, the distance between the holes, their sealing depth, and the required volume of water. The water infusion method has some limitations, however. For example, it is not used for seams with a water saturation level of over $12 \%$, low moisture capacity (up to $2 \%$ ) or low porosity (up to $5 \%$ ).

The effectiveness of water infusion $(\eta)$ depends on physical and filtration-related properties of the seam, as well as on the hole parameters and the chosen water delivery method (Pozdnjakov et al.,1982):

$$
\eta=\mu \cdot \frac{q_{l}}{n_{e}} \cdot 100
$$

Where:

$\mu$ - factor of proportionality;

$q_{l}-$ liquid discharge intensity, $\mathrm{m}^{3} / \mathrm{t}$;

$n_{e}$ - effective porosity, $\%$.

The effectiveness of the water infusion method varies from 50 to $80 \%$. The highest reduction in dustiness (up to $80 \%$ ) after the infusion was observed in the mines of the Pechora basin. The lowest effectiveness was observed in the coal beds of Donetsk and Karaganda basins. In those mines, the effectiveness of water infusions did not exceed $55 \%$.

The full range of dust suppression measures that are to be carried out during the mining process (tunnelling, extraction, transporting, transhipment, etc.) is provided in the regulations (Federal regulations on industrial safety. Regulations on explosion prevention of dusty gas-air atmospheres in coal mines, 2013; Federal regulations on industrial safety. Instructions on dust control in coal mines, 2019).

The international experience on dust suppression (American, Australian, African, Chinese, Indian) shows that the most effective methods of dust reduction in longwall faces involve the following:

- maintaining air flows of optimal speed to prevent dust from rising, and to prevent the formation of static dust clouds (Gendler and Nguen, 2018; Colinet et al., 2010);

- taking advantage of splitter arms on the shearer to separate the working area and the zone with the highest dust concentration (Colinet et al., 2010);

- installing additional jet fans and nozzles to ensure faster dust removal and better dust suppression (Colinet et al., 2010);

- installing water-mist-based Venturi systems along longwalls (Ren et al., 2011);

- equipping shearers with scrubbers to provide dust extraction and dust suppression in the drum area (Ren et al., 2011; Ren et al., 2011);

- using sprinkling techniques that involve mixing the water with surfactants to improve the effectiveness of coal dust wetting (Wang et al., 2016; Wang et al., 2016).

It should be noted that, in some cases, the parameters and application areas for dust suppression methods are chosen based on the data on dust distribution along the longwall's length and cross-section. There exist specialized 
software solutions (such as Ansys and flowvision) that are used to model the dust distribution within the mine and thus provide a more reliable picture of the dust conditions therein (Smirnov and Ivanov, 2018).

Analysis of the existing patents for dust-wetting and dust-suppressing solutions has shown this avenue of research to be very promising, given the great number of registered formulas (Glebov, 2013; Zhmaev and Kuznecov, 2019; Konabe and Kavazoe, 2010; Lobanov et al., 2014; Joao, 2008).

When it comes to Russian mines, the most commonly used wetting agents are anionic and nonionic sulfactantbased ones by Elfor-M. Some mines use wetting agents by SMUG and Neolas, but these are not as common due to their relatively lower wetting ability.

These days, the research for more effective and less harmful wetting agents is conducted in both Russia and abroad (Kovshov and Kovshov, 2017; Wang et al., 2016; Wang et al., 2016), which is indicative of the fact that the currently used wetting agents do have a number of shortcomings (such as low wetting ability, high production costs, and adverse effects on the environment, workers and the extracted materials themselves).

\section{Material and Methods}

The research included the following:

- on-site measuring of dustiness levels in high-yielding longwall faces at various Russian coal mines;

- laboratory testing of dispersion composition of airborne dust taken from longwall faces;

- analysis of factors determining the dust conditions;

- laboratory research on a new wetting agent;

- on-site testing of the newly-developed dust suppression method.

The dust concentration was measured using the PKA-01 and AERA portable dust samplers at three locations: directly next to the shearer (operator working space), 5-6 meters away from the shearer along the air jet direction (canopy operator working space), and 10-15 meters away from the canopy operator's space (Fig. 3).

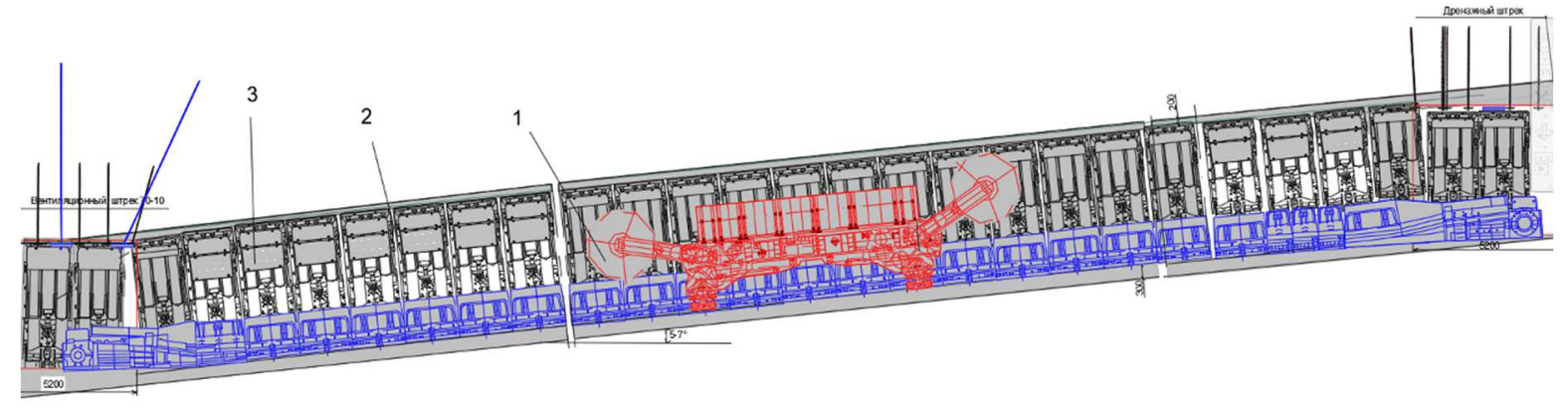

Fig. 3. Location of measurement points for dustiness tests in longwall faces

1 -directly next to the shearer; 2 - 5-6 $m$ away from the shearer, 3-10-15 m away from the shearer (Source: Authors)

Additionally, dust samplings were taken at specified locations using dust filters (Fig. 4). They were then transported to a laboratory for dispersion composition testing. Particle-size analysis of the aerosol was conducted using electron microscopy (Fig. 5).

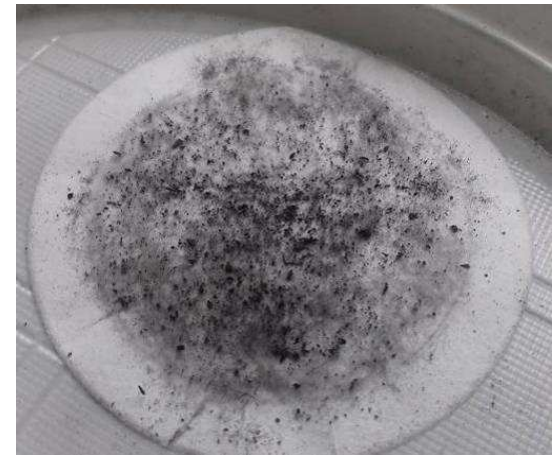

Fig. 4. Coal dust sampled on a filter (Source: Authors)

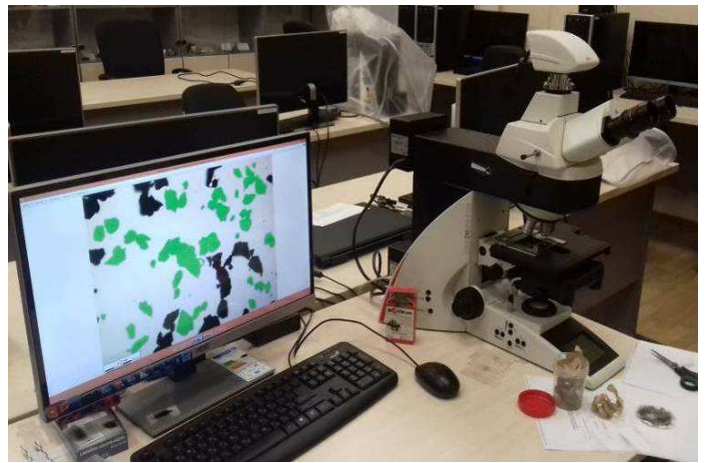

Fig. 5. Process of sample analysis via the "Leica DM4000 B LED” electronic microscope and corresponding software (Source: Authors)

Each section of the filter was studied at 100x magnification. The images were processed using specialized software that would provide data on the number and parameters of the detected particles (their corresponding diameter and area). A single sampling counted no fewer than 3,500 particles, sized 0.656-987 $\mu \mathrm{m}$. The standard deviation of $\sigma$ did not exceed $0.0628 \mathrm{~mm}$. 
The type of dependence of the dustiness level and the aerosol particle size on various factors was determined using correlation and regression analysis. The baseline data for the analysis is presented in Tab. 3 .

Tab. 3. Dust sampling conditions

\begin{tabular}{|c|c|c|c|c|}
\hline \multirow[b]{2}{*}{ Parameter } & \multicolumn{4}{|c|}{ Mine name } \\
\hline & A.D. Ruban & $\begin{array}{l}\text { Taldinskaya- } \\
\text { Zapadnaya-2 }\end{array}$ & V.D. Yalevsky & S.M. Kirov \\
\hline Seam name & Polysaevsky-2 & 70 & 52 & Boldyrevsky \\
\hline Coal grade & Д (D) & Д (D) & ДГ (DG) & $\Gamma(\mathrm{G})$ \\
\hline Seam thickness, $[\mathrm{m}]$ & 4.70 & 4.81 & 4.34 & 2.55 \\
\hline Hardness coefficient, $\mathrm{f}$ & 2.5 & 1.8 & 2.5 & 1.5 \\
\hline Moisture content, $\mathrm{W}_{\mathrm{t}}^{\mathrm{r}},[\%]$ & 8.5 & 11.9 & 9.0 & 4.11 \\
\hline Ash content, $\mathrm{A}_{\mathrm{ex}}^{\mathrm{d}},[\%]$ & 12.0 & 13.0 & 13.5 & 35.4 \\
\hline $\mathrm{Al}_{2} \mathrm{O}_{3}$ content in ash, $\beta_{\mathrm{Al} 2 \mathrm{O} 3},[\%]$ & 16.6 & 23.4 & 25.6 & 20.5 \\
\hline $\mathrm{SiO}_{2}$ content in ash, $\beta_{\mathrm{SiO} 2},[\%]$ & 60.4 & 60.9 & 61.6 & 63.7 \\
\hline Inertinite content, $\mathrm{I},[\%]$ & 8.0 & 15.0 & 15.6 & 5.0 \\
\hline Shearer type & SL-500 & SL-500 & SL-500 & Joy 7 LS-20 \\
\hline Shearer productivity, $\mathrm{P},[\mathrm{t} / \mathrm{min}]$ & $11.99-12.15$ & $14.70-14.80$ & 20.71-20.82 & $14.19-14.25$ \\
\hline $\begin{array}{l}\text { Face output, } \\
\mathrm{Q},[\mathrm{t} / \mathrm{h}]\end{array}$ & $719.1-728.7$ & $882.1-888.0$ & 1242.51249 .0 & $851.1-854.8$ \\
\hline Air flow speed, $\mathrm{v},[\mathrm{m} / \mathrm{s}]$ & $1.15-1.38$ & $0.79-1.11$ & $2.10-3.54$ & 3.67 \\
\hline
\end{tabular}

The development of a wetting agent contained several stages: selection of promising components, assessment of wetting ability and properties of various surfactants and their mixes, laboratory testing and on-site testing of the new wetting agent with a concurrent assessment of usability parameters. The initial stages of the project involved a comparative analysis of the commonly used wetting agent by Elfor-M, its dynamic viscosity (Fig. 6) and pH (Fig. 7) for solutions with different concentration levels.

After that came the assessment of the wetting ability of the various selected surfactants in regards to the coal dust from the aforementioned seams. For that purpose, lumpy coal samples would be crushed into pieces of $63 \mu \mathrm{m}$. Dust sample of $0.1 \mathrm{~g}$ would be placed into a prepared surfactants solution, and the time until full submersion would be measured with a stopwatch (Fig. 8). A shorter submersion time would signify better wetting ability. As per (STO 00173769-005-2014), the threshold for the optimal wetting ability of solutions was understood to be $60 \mathrm{~s}$.

The on-site testing of the dust wetting solutions involved injecting them into the spraying systems of the shearers (Fig. 9) and taking measurements of dustiness during the shearing. Additionally, the tests incorporated air sampling for airborne dust particle distribution analysis.

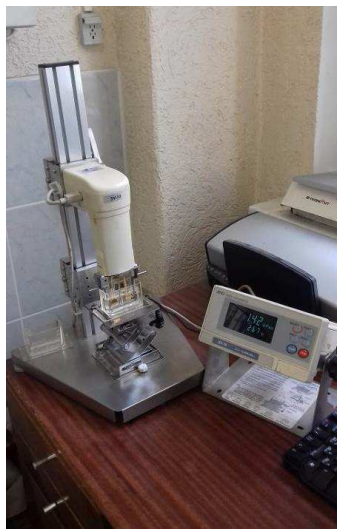

Fig. 6. Viscosity analysis using SV-10 vibro-viscosimeter (Source: Authors)

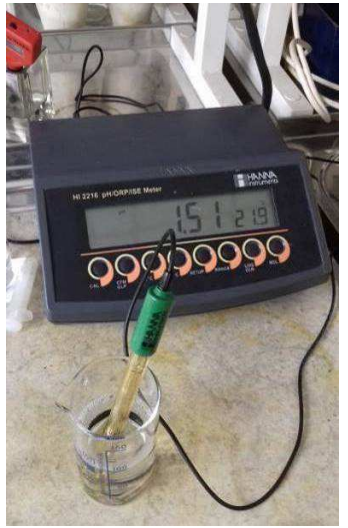

Fig. 7. Analysis of pH levels using HI 2216 pH-meter by HANNA Instruments (Source: Authors) 
The same method was used to compare the effectiveness of the new wetting agent and the Elfor-M wetting agent.

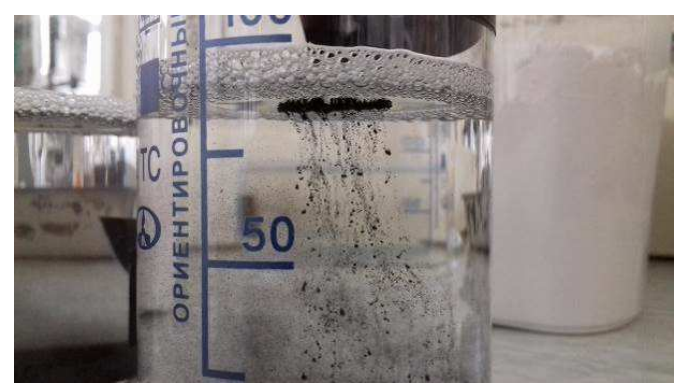

Fig. 8. Assessment of surfactant viscosity (Source: Authors)
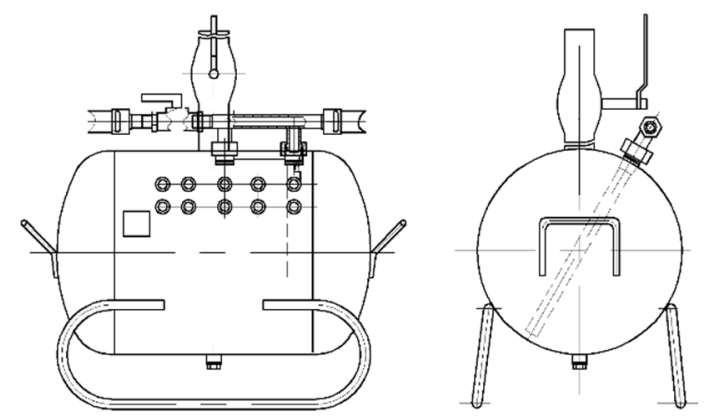

Fig. 9. DS-50/200 wetting dosing system (Source: Wetting dosing system DS, 2020)

\section{Results and discussion}

The following Tab. 4 contains the data compiled at the longwall faces of the SUEK-Kuzbass (JSC) mines following the procedures on measuring dust concentration and particle size analysis, as outlined above. The results are presented in the table and Fig. 10-12.

\begin{tabular}{|c|c|c|c|c|c|c|c|c|}
\hline \multirow{3}{*}{ Measurement site } & \multicolumn{8}{|c|}{ Average dustiness values $\mathrm{C},\left[\mathrm{mg} / \mathrm{m}^{3}\right]$ at longwall faces } \\
\hline & \multicolumn{2}{|c|}{ A.D. Ruban } & \multicolumn{2}{|c|}{ Taldinskaya-Zapadnaya-2 } & \multicolumn{2}{|c|}{ V.D. Yalevsky } & \multicolumn{2}{|c|}{ S.M. Kirov } \\
\hline & $\begin{array}{c}\mathrm{C},\left[\mathrm{mg} / \mathrm{m}^{3}\right] \\
\text { (AERA) }\end{array}$ & $\begin{array}{c}\mathrm{C},\left[\mathrm{mg} / \mathrm{m}^{3}\right] \\
\text { (PKA) }\end{array}$ & $\begin{array}{c}\mathrm{C},\left[\mathrm{mg} / \mathrm{m}^{3}\right] \\
\text { (AERA) }\end{array}$ & $\begin{array}{c}\mathrm{C},\left[\mathrm{mg} / \mathrm{m}^{3}\right] \\
\text { (PKA) }\end{array}$ & $\begin{array}{c}\mathrm{C},\left[\mathrm{mg} / \mathrm{m}^{3}\right] \\
\text { (AERA) }\end{array}$ & $\begin{array}{c}\mathrm{C},\left[\mathrm{mg} / \mathrm{m}^{3}\right] \\
\text { (PKA) }\end{array}$ & $\begin{array}{c}\mathrm{C},\left[\mathrm{mg} / \mathrm{m}^{3}\right] \\
\text { (AERA) }\end{array}$ & $\begin{array}{c}\mathrm{C},\left[\mathrm{mg} / \mathrm{m}^{3}\right] \\
\text { (PKA) }\end{array}$ \\
\hline Next to shearer & 194.44 & 178.29 & 184.38 & 200.57 & 221.57 & 238.8 & 47.67 & 42.5 \\
\hline 5-6 $\mathrm{m}$ from shearer & 138.89 & 155.01 & 100.00 & 85.48 & 198.67 & 198.17 & 27.86 & 26.61 \\
\hline $\begin{array}{l}10-15 \mathrm{~m} \text { from } \\
\text { shearer }\end{array}$ & 83.33 & 81.16 & 25 & 39.23 & 172.2 & 184.8 & 40.61 & 40.73 \\
\hline
\end{tabular}

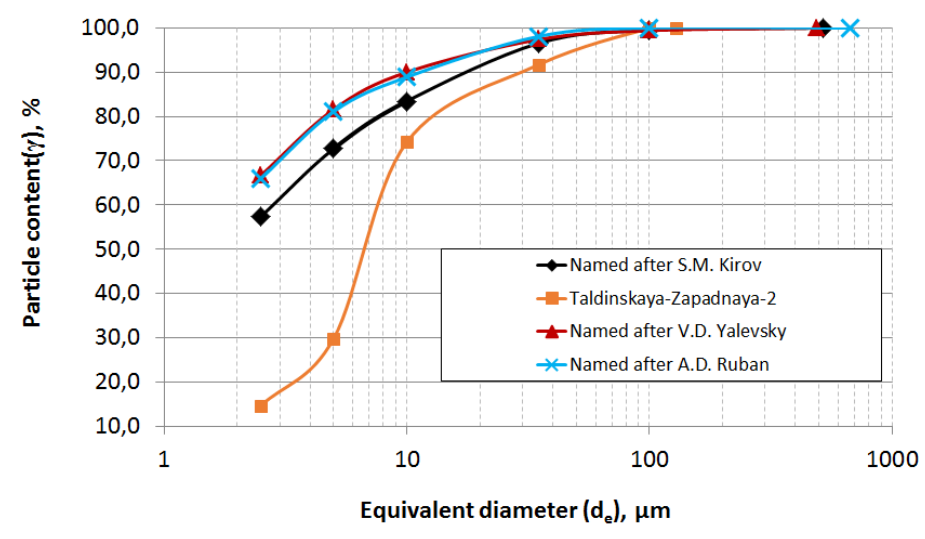

Fig. 10. Results of dust particle size distribution analysis (next to shearer)(Source: Authors) 


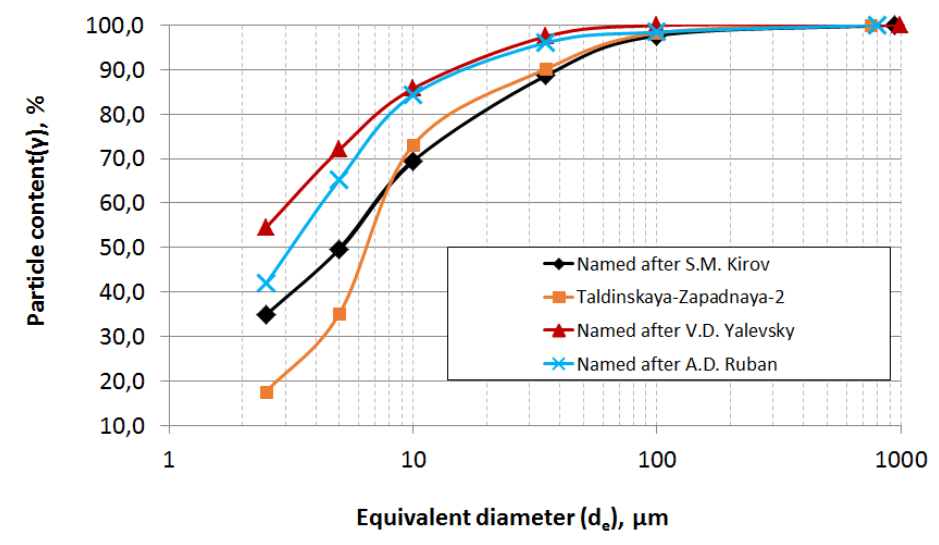

Fig. 11. Results of dust particle size distribution analysis (5-6 m from shearer) (Source: Authors)

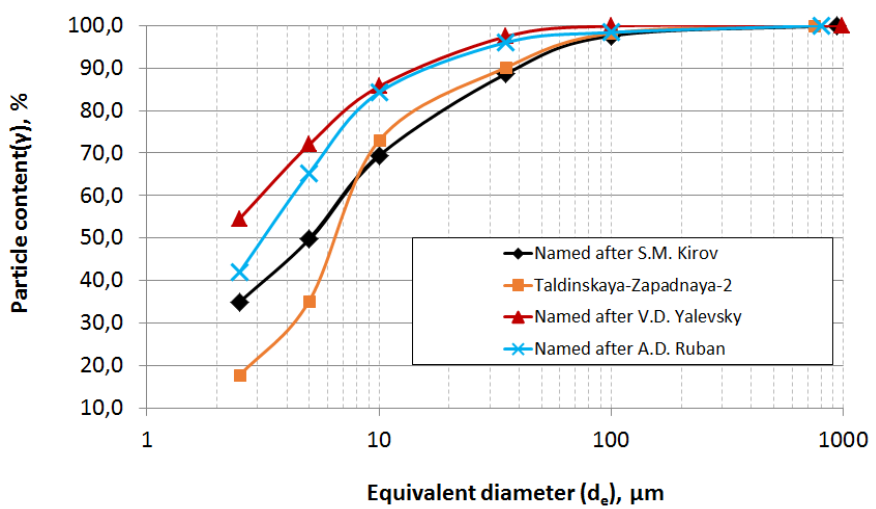

Fig. 12. Results of dust particle size distribution analysis (10-15 m from shearer) (Source: Authors)

Analysis of the acquired data shows that with the increased distance, the level of dustiness and the content of the finely dispersed particles in the aerosol decrease. For instance, while next to the shearer particles under $35 \mu \mathrm{m}$ account for 91.8-98.1\% of the aerosol, at $15 \mathrm{~m}$ away from it, their share falls to 75.6-89.7 \%. At the same time, it should be noted that the dust content of respirable (up to $10 \mu \mathrm{m}$ ) and thoracic fractions (up to $35 \mu \mathrm{m}$ ) at the same workspaces of different mines is markedly different from each other. As such, the highest content of finely dispersed particles at the shearer operator's work spaces was observed at the V.D. Yalevsky and A.D. Ruban mines: $\gamma_{0,1-10}=90.0 \%, \gamma_{0,1-10}=88.8 \%$ and $\gamma_{0,1-35}=97.4 \%, \gamma_{0,1-35}=98.1 \%$, respectively. Given the higher dustiness levels at these mines, the amount of finely dispersed particles reaching the workers' lungs and bronchi is going to be bigger.

In order to be able to take appropriate protective measures in a timely manner and ensure working safety (such measures include, for example, adjusting operation hours of mining equipment and dust suppression mechanisms, taking steps to reduce dustiness and concentration of fine dust, limiting the time of stay for workers operating in hazardous zones, issuing better personal respiratory protective equipment (PPE), etc.), it is necessary to constantly monitor the dust environment and predict changes in it. The results of the correlation and regression analysis of the collected data and adjacent factors allowed for the creation of mathematical models that can predict changes in the air of the longwall faces: changes in airborne dust concentration (Eq. 2) and in the contents of individual small fractions — respirable (Eq. 3) and thoracic (Eq. 4).

$$
C=-232.71+57.88 \cdot f+0.94 \cdot t+24.92 \cdot m+7.73 \cdot P-5.23 \cdot R
$$

Where:

$C$ - actual dust concentration at the measurement point, $\mathrm{mg} / \mathrm{m}^{3}$;

$f$ - coal hardness coefficient as per prof. M.M. Protodyakonov scale;

$t$ - wetting time for finely dispersed coal particles, sec.;

$m$ - extracting seam thickness, $\mathrm{m}$;

$P$ - shearer productivity, $\mathrm{t} / \mathrm{min}$.;

$R$ - distance from shearer to measurement point, $\mathrm{m}$.

$$
\gamma_{0.1-10}=50.18+12.35 \cdot f-0.43 \cdot W_{t}^{r}+0.83 \cdot P-1.58 \cdot R
$$




$$
\gamma_{0.1-35}=80.4+4.65 \cdot f-0.04 \cdot W_{t}^{r}+0.45 \cdot P-0.96 \cdot R
$$

Where:

$\gamma_{0.1-10,}, \gamma_{0.1-35}$ - respective fractions of respirable and thoracic particles in total mass of airborne dust, $\%$;

$f$ - coal hardness coefficient;

$W^{r}$ - water saturation of extracted coal, \%;

$P$ - shearer productivity, $\mathrm{t} / \mathrm{min}$;

$R$ - distance from shearer to measurement point, $\mathrm{m}$.

It has been proven that the timing of wetting of dust particles during the formation of dust clouds (i.e. shearing of coal) has a great impact on the dustiness levels. Data also shows that the speed of dust suppression depends not only on the size difference between the water droplets and dust particles but also on the spraying speed, which itself depends on the type and concentration of the wetting agent, as well as on the properties of dust.

In this regard, it is recommended to use the following formulas for predicting the fine dust contents in the areas next to the shearers (the denotations of the symbols have been provided above):

$$
\begin{aligned}
& \gamma_{0.1-10}=65.2+16.51 \cdot f-1.85 \cdot W_{t}^{r}+0.34 \cdot P-0.1 \cdot t \\
& \gamma_{0.1-35}=88.47+3.66 \cdot f-0.53 \cdot W_{t}^{r}+0.03 \cdot P-0.1 \cdot t
\end{aligned}
$$

It is recommended to use a wetting agent that includes nonionic (decylglucoside and cocoglucoside) and amphoteric (kokamidopropylbetaine) surfactants to reduce dustiness and concentration of the most hazardous fine dust particles. The experiments (Fig. 13) show that composition 2, made of the aforementioned components, displayed the highest wetting ability when used on $G(\Gamma)$ grade coal dust from the Breevsky seam of the Polysaevskaya mine, and when used on coal dust from other seams (Fig. 14).

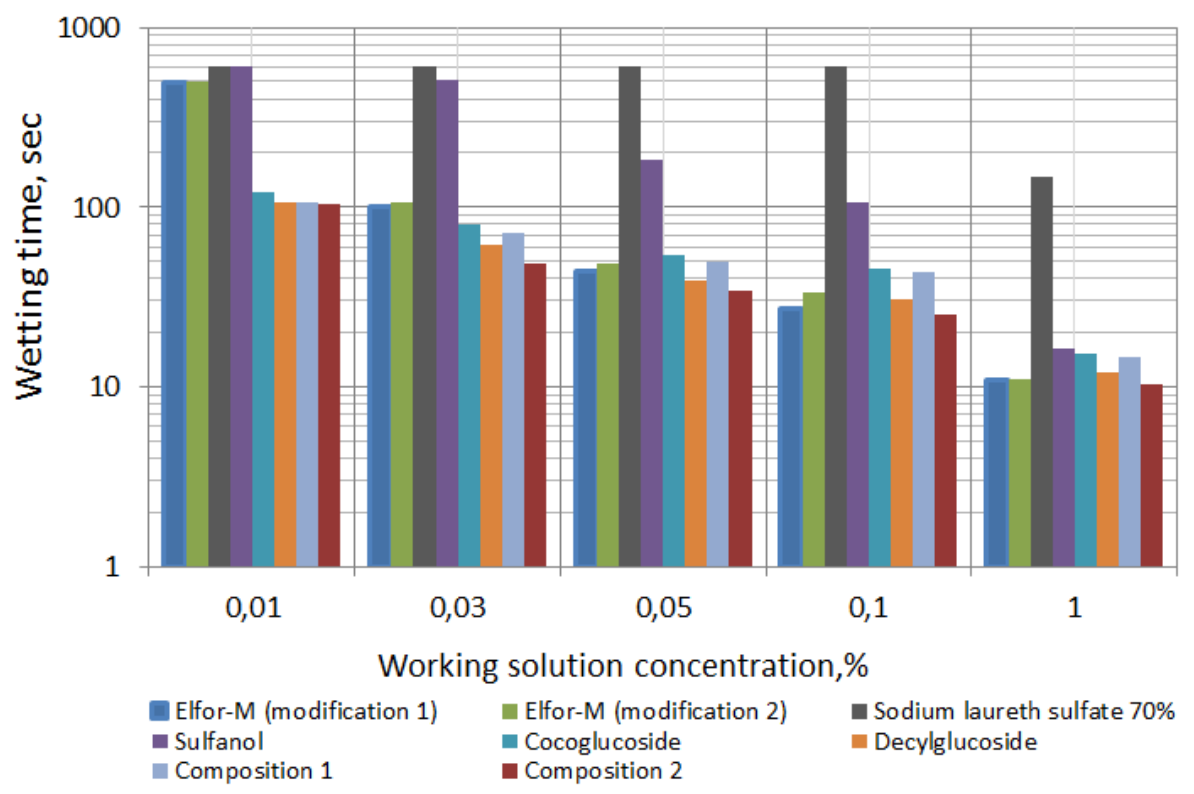

Fig. 13. Assessment of the wetting ability of $1 \%$ surfactant solutions (Source: Authors) 


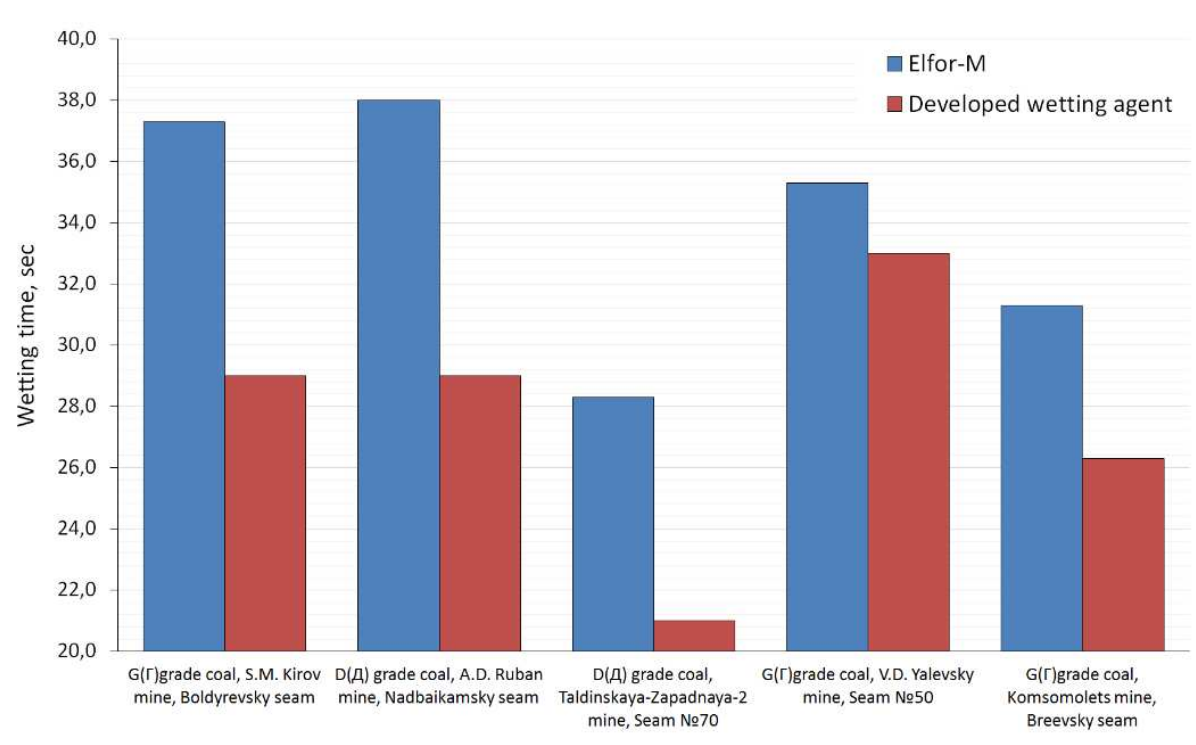

Fig. 14. Effectiveness assessment of the developed solution tested on coal dust from various seams (0.1\% solutions used)(Source: Authors)

The on-site (longwall face at the Polysaevskaya mine) testing of the developed wetting agent has proven its effectiveness when compared to the commonly used wetting agent. (Tab. 5 and Tab. 6).

\begin{tabular}{|c|c|c|c|c|c|c|}
\hline \multirow{3}{*}{ № } & \multirow{3}{*}{ Seam name } & \multirow{3}{*}{$\begin{array}{l}\text { Measurement } \\
\text { point for } \\
\text { dustiness }\end{array}$} & \multirow{3}{*}{$\begin{array}{l}\text { Airflow } \\
\text { speed, } \\
{[\mathrm{m} / \mathrm{s}]}\end{array}$} & \multirow{3}{*}{ Work type } & \multirow{2}{*}{\multicolumn{2}{|c|}{$\begin{array}{l}\text { Average mass concentration of dust, } \mathrm{mg} / \mathrm{m} 3 \\
\text { upon using a wetting agent }\end{array}$}} \\
\hline & & & & & & \\
\hline & & & & & Elfor-M & Experimental agent \\
\hline 1 & $19-01$ & $\begin{array}{c}\text { Shearer } \\
\text { operator } \\
\text { workspace }\end{array}$ & 0.66 & Coal/rock shearing & 224.0 & 188.8 \\
\hline 2 & $19-01$ & $\begin{array}{l}30 \mathrm{~m} \text { away } \\
\text { from shearer }\end{array}$ & 0.32 & Coal/rock shearing & 160.0 & 143.6 \\
\hline
\end{tabular}

\begin{tabular}{|c|c|c|c|c|c|c|c|c|c|c|c|}
\hline \multirow[t]{2}{*}{ Measurement point } & \multirow[t]{2}{*}{ Test № } & \multicolumn{10}{|c|}{ Particles with equivalent diameter per fraction, $\gamma,[\%]$} \\
\hline & & $\begin{array}{c}0.656- \\
2.5 \\
{[\mu \mathrm{m}]} \\
\end{array}$ & $\begin{array}{l}2.5-5 \\
{[\mu \mathrm{m}]}\end{array}$ & $\begin{array}{r}5-10 \\
{[\mu \mathrm{m}]} \\
\end{array}$ & $\begin{array}{l}10-35 \\
{[\mu \mathrm{m}]}\end{array}$ & $\begin{array}{c}35-100 \\
{[\mu \mathrm{m}]} \\
\end{array}$ & $\begin{array}{l}100- \\
1000 \\
{[\mu \mathrm{m}]}\end{array}$ & $\begin{array}{c}0.1-10 \\
{[\mu \mathrm{m}]} \\
\end{array}$ & $\begin{array}{c}0.1-35 \\
{[\mu \mathrm{m}]} \\
\end{array}$ & $\begin{array}{c}\text { Avg. } \\
0.1-10 \\
{[\mu \mathrm{m}]}\end{array}$ & $\begin{array}{c}\text { Avg. } \\
0.1-35 \\
{[\mu \mathrm{m}]} \\
\end{array}$ \\
\hline \multirow{3}{*}{$\begin{array}{l}\text { Shearer operator } \\
\text { work space }\end{array}$} & 1 & 44.6 & 16.6 & 14.4 & 22.8 & 1.5 & 0.1 & 75.6 & 98.4 & \multirow{3}{*}{75.3} & \multirow{3}{*}{98.9} \\
\hline & 2 & 41.9 & 17.1 & 15.3 & 25.0 & 0.5 & 0.2 & 74.3 & 99.3 & & \\
\hline & 3 & 43.1 & 16.5 & 16.5 & 23.0 & 0.8 & 0.1 & 76.1 & 99.1 & & \\
\hline \multirow{3}{*}{$\begin{array}{c}30 \mathrm{~m} \text { away from } \\
\text { shearer }\end{array}$} & 4 & 33.8 & 14.5 & 14.8 & 19.2 & 12.3 & 5.4 & 63.1 & 82.3 & \multirow{3}{*}{63.8} & \multirow{3}{*}{83.0} \\
\hline & 5 & 34.5 & 15.1 & 13.2 & 20.1 & 12.5 & 4.6 & 62.8 & 82.9 & & \\
\hline & 6 & 34.9 & 14.8 & 15.7 & 18.4 & 10.0 & 6.2 & 65.4 & 83.8 & & \\
\hline \multirow{3}{*}{$\begin{array}{l}\text { Shearer operator } \\
\text { work space }\end{array}$} & 7 & 22.2 & 15.5 & 20.5 & 14.7 & 19.4 & 7.7 & 58.2 & 72.9 & \multirow{3}{*}{59.2} & \multirow{3}{*}{74.6} \\
\hline & 8 & 23.8 & 14.3 & 22.0 & 16.0 & 17.8 & 6.1 & 60.1 & 76.1 & & \\
\hline & 9 & 22.4 & 16.6 & 20.2 & 15.6 & 18.6 & 6.6 & 59.2 & 74.8 & & \\
\hline \multirow{3}{*}{$\begin{array}{c}30 \text { m away from } \\
\text { shearer }\end{array}$} & 10 & 14.7 & 13.3 & 19.6 & 14.3 & 23.6 & 14.5 & 47.6 & 61.9 & \multirow{3}{*}{48.8} & \multirow{3}{*}{64.4} \\
\hline & 11 & 15.9 & 14.5 & 18.3 & 15.8 & 20.9 & 14.6 & 48,7 & 64.5 & & \\
\hline & 12 & 15.0 & 14.9 & 20.1 & 16.7 & 21.2 & 12.1 & 50.0 & 66.7 & & \\
\hline
\end{tabular}


The effective decrease in dust concentration when using a $0.05 \%$ wetting agent solution was observed to be at $10.3-15.7 \%$. The respirable dust fraction was reduced by $19.1-24.6 \%$ and the thoracic fraction was reduced by 20.4-25.9\%.

\section{Conclusions}

The main issues holding back the improvement of the dust conditions in the longwall faces are as follows: high work intensity, untimely and often exclusively nominal dust control measures; failure to perform maintenance of underground equipment and dust suppression devices in a timely manner; uninformed and arbitrary selection of dust reduction tools, methods and their ways of application; inflexibility of dust control systems and, as a result, their inability to dynamically change the modes and parameters of dust control based on the operational and projected data.

International dust control practices involve continuous efforts towards betterment and improvement of the existing means of dust reduction (such as the implementation of modern Venturi systems or redesign of spraying nozzles), efforts aimed at increasing the seams' water saturation levels, adoption of new equipment (scrubbers, aspiration systems, splitter arms), as well as utilization of a computer-based particle size analysis with projections on future dust conditions, which makes it possible to make informed decisions on dust control methods and their application.

With increasing dust dispersion levels-elevated by an increasing energy intensity and growing capabilities of mining efforts - it is vital to monitor the fine dust particle content of the air and to make projections on its fluctuations. For that purpose, a number of mathematical models have been developed, capable of taking into account the influence of a multitude of factors on the projected dustiness levels and aerosol dispersion composition, factors such as: water saturation levels and hardness levels of coal, and even shearer productivity.

The principal means of dust suppression proposed hereby is a newly developed wetting agent, proven to be effective both in laboratory testing and during on-site testing. Aside from that, other ways to improve dust suppression in longwall faces include optimizing the timing of water spraying, maintaining a stable shearing intensity, performing timely maintenance of nozzles and other dosing and dedusting devices, and performing timely maintenance on the shearer parts in order to manage the shearing intensity and dust formation.

\section{References}

Air quality guidelines: global update 2005. Particulate matter, ozone, nitrogen dioxide and sulfur dioxide (2006). Copenhagen, WHO Regional Office for Europe. Available at: http://www.euro. who.int/en/what-wedo/health-topics/environment-and-health/air-quality/publications/ pre2009/air quality-guidelines.-globalupdate-2005.-particulate-matter,-ozone,-nitrogen-dioxide-and-sulfur-dioxide.

BP Statistical Review of World Energy (2020). Available at: https: www.bp.com/content/dam/bp/businesssites/en/global/corporate/pdfs/energy economics/statistical-review/bp-stats-review-2020-full-report.pdf

CFT GmbH Compact Filter Technic. Consistently high quality. Dry dedusting, wet dedusting, dedusting for dry drilling (2020). Available at: https:cft-gmbh.de/ru/obespylivanie.

Chebotarjov, A. G. (2019). Special assessment of working conditions of coal mine workers. Russian Mining Industry, 1(143), 42-46. http://dx.doi.org/10.30686/1609-9192-2019-1-143-42-44

Chemezov, E. N. (2019) Industrial safety principles for coal mining. Journal of Mining Institute, 240, 649-653. https://doi.org/10.31897/pmi.2019.6.649

Colinet, J. F., Rider, J. P., Listak, J. M., Organiscak, J. A. and Wolfe, A. L. (2010). Best practices for dust control in coal mining. DHHS (NIOSH) Publication, Pittsburgh, PA, Spokane, WA. 76. https://doi.org/10.26616/nioshpub2010110

Danilov, A. S., Smirnov, Y. D. and Korelskiy, D. S. (2017). Effective methods for reclamation of area sources of dust emission. Journal of Ecological Engineering, 18(5), 1-7. https://doi.org/10.12911/22998993/74947

Directive 2008/50/EC of the European Parliament and of the Council of 21 May 2008 on ambient air quality and cleaner air for Europe (2008). Available at: http://eurlex.europa.eu/LexUriServ/LexUriServ.do?uri=OJ:L:2008:152:0001:0044:EN:PDF

Federal regulations on industrial safety. Instructions on dust control in coal mines (2019), approved by Federal Service for Ecological, Technological and Atomic Supervision on 25.09.2018. No 462. series 05. issue 44. Scientific technical center of industrial safety problems research, Moscow.

Federal regulations on industrial safety. Regulations on explosion prevention of dusty gas-air atmospheres in coal mines (2013), approved by Federal Service for Ecological, Technological and Atomic Supervision on 06.11.2012. No 634. series 05. issue 25. Scientific technical center of industrial safety problems research, Moscow. 
Gendler, S. G., Rudakov, M. L. and Kuznetsov, V. S. (2019) Evaluation principles of the dust influence of mining enterprises on the environment. Latvian Journal of Physics and Technical Sciences, 3, 62-69. https://doi.org/10.2478/lpts-2019-0020

Gendler, S. G. and Nguen, T. H. (2018). Justification of Rational Methods for Provision of Air to Faces of Operating Coal Mines of Vietnam During Deepening of Mines. Journal of Mining Institute, 234, $652-657$. https://doi.org/10.31897/pmi.2018.6.652

Glebov, A.F. (2013). Wetting agent for coal dust suppression. Russia, Pat. no. 2495250.

Han, L., Han, R., Ji, X., Wang, T., Yang, J., Yuan, J., Wu, Q., Zhu, B., Zhang, H., Ding, B. and Ni, C. (2015). Prevalence Characteristics of Coal Workers' Pneumoconiosis (CWP) in a State-Owned Mine in Eastern China Int J Environ Res Public Health, 12, 7856-7867. https://doi.org/10.3390/ijerph120707856

Ji, Y. Ting, R., Wynne, P., Wan, Z., Ma, Z. and Wang, Z. (2016). A comparative study of dust control practices in Chinese and Australian longwall coal mines. International Journal of Mining Science and Technology, 26, 199-208. https://doi.org/10.1016/j.ijmst.2015.12.004

Joao, R. (2008). Surfactant solution for suppression. USA, Pat. no. 20080017829.

Kharitonov, I. L., Tereshkin, A. I., Kornev, A. V., Korshunov, G. I. and Korneva, M. V. (2019) Development of Measures on the Improvement of Dust Environment in the Coal Mines Working Faces. Occupational Safety in Industry, 12, 53-59. https://doi.org/10.24000/0409-2961-2019-12-53-59

Konabe, K. and Kavazoe M. (2010). Dust-binding solution. Russia, Pat. no. 2391375.

Korshunov, G. I. and Romanchenko, S. B. (2016). Development of innovative technologies of dedusting in mining and advance coal mine faces. Journal of Mining Institute. 218, 339-344.

Kovshov, S. V. and Barkan, M. Sh. (2016). Reduction of dust emission in transshipping processes at sea ports. International Journal of Ecology and Development, 31(2), 50-59.

Kovshov, S. V. and Kovshov, V. P. (2017). Improving efficiency of dust suppression during underground coal mining using surfactants. The European Proceedings of Social \& Behavioural Sciences, 26, 489-496. https://doi.org/10.15405/epsbs.2017.07.02.63

Lobanov, F. I., Chukalina, E. M., Kozlov, L. N., Globa, E. Ju. and Kaplunov V. Ju. (2014). Fixation method for dusty surfaces. Russia, Pat. no. 2513786.

Magomet, R. D., Rodionov, V. A. and Solovev, V. B. (2019) Methodological approach to issue of researching dust-explosion protection of mine workings of coal mines. International Journal of Civil Engineering and Technology, 10(2), 1154-1161. Available at: https://www.iaeme.com/MasterAdmin/Journal_uploads/IJCIET/VOLUME_10_ISSUE_2/IJCIET_10_02_1 12.pdf

Pope, C. A., Burnett, R. T., Thun, M. J., Calle, E. E., Krewski, D., Ito, K. and Thurston, G. D. (2002). Lung cancer, cardiopulmonary mortality, and long-term exposure to fine particulate air pollution. JAMA, 287(9), 11321141. https://doi.org/10.1001/jama.287.9.1132

Pozdnjakov, G. A., Kirin, B. F., Voroncova, E. I. and Ontin, E. I. (1982). Manual on dust control in the mining industry. Nedra, Moscow, 233.

Projections on social and economic development of Russia for the period up to 2036 (2018). Approved by Russian government 22.11.2018. Available at: https://www.economy.gov.ru/ material/file /a5f3add5deab665b344b47a8786dc902/ prognoz2036.pdf

Qian, X. Liu, L., Leung, E. and Tang, Y. (2016). Clinical statistics analysis on the characteristics of pneumoconiosis of Chinese miner population. Journal of Thoracic Disease, 8(8), 2203-2211, https://doi.org/10.21037/jtd.2016.07.53

Ren, T. X., Plush, B. and Aziz, N. (2011). Dust controls and monitoring practices on Australian longwalls. 1st International Symposium on Mine Safety Science and Engineering, ISMSSE, 1182-1194. https://doi.org/10.1016/j.proeng.2011.11.2319

Ren, T. G., Cooper, G. and Yarlagadda, S. (2011). Development of a water-mist based Venturi system for dust control from maingate chocks and BSL. 11th Underground Coal Operators' Conference, University of Wollongong \& the Australasian Institute of Mining and Metallurgy, 239-248. Available at: https://ro.uow.edu.au/cgi/viewcontent.cgi?article=6512\&context=engpapers

Romanchenko S. B., Timchenko, A. N., Kosterenko V. N., Pozdnjakov G. A., Rudenko Ju. F., Artem'ev, V. B. and Kopylov, K. N. (2016). Complex dust reduction measures. Mining, Kimmerijskij centr, Moscow, 288.

Romanchenko, S. B., Rudenko Ju. F. and Kosterenko V. N. (2011). Dust dynamics in coal mines. Mining, Kimmerijskij centr, Moscow, 256.

Samoli, E., Peng, R., Ramsay, T., Pipikou, M., Touloumi, G., Dominici, F., Burnett, R., Cohen, A., Krewski, D., Samet, J. and Katsouyanni, K. (2008). Acute effects of ambient particulate matter on mortality in Europe and North America: results from the APHENA Study. Environmental Health Perspectives, 116(11), 1480-1486. https://doi.org/10.1289/ehp.11345 
Smirnov, Y. D. and Ivanov, A. V. (2018). Investigation of dust transfer processes during loading and unloading operations using software simulation. Journal of Ecological Engineering, 19(4), 29-33. https://doi.org/10.12911/22998993/86146

Smirnyakov, V. V. and Smirnyakova, V. V. (2016). Unhandy factors in statistics of accidental gas and dust explosions in coal mines in Russia. Ghornyi Zhurnal, 1, 30-34. https://doi.org/10.17580/gzh.2016.01.07

State report on the state of sanitary and epidemiological well-being of the Russian population (2019). Russian Federal Service for Surveillance on Consumer Rights Protection and Human Wellbeing. Moscow.

STO 00173769-005-2014. Methods for determining wetting ability of surfactants on coal mine dust. NC VostNII, Kemerovo.

Tarazanov, I. G. and Gubanov, D. A. (2020). Report on Russian coal mining industry for the period of JanuaryDecember of 2019 [Itogi raboty ugol'noj promyshlennosti Rossii za janvar'-dekabr' 2019 goda]. Coal. 3, 5469. http://dx.doi.org/10.18796/0041-5790-2020-3-54-69

Wang, W. Z., Wang, Y. M., and Shi, G. Q (2016). Optical estimation on pollution level of respirable dust based on infrared transmitting behavior in coal mine fully mechanized working face. Journal of Spectroscopy, 113. https://doi.org/10.1155/2016/2626414

Wang, W. Z., Wang, Y. M., and Shi, G. Q. (2016). Waveband selection within 400-4000 cm-1 of optical identifcation of airborne dust in coal mine tunneling face. Applied Optics, 55(11), 2951-2959. https://doi.org/10.1364/ao.55.002951

Wang, M., Li, R., Li, Y., Cheng, X., Yang, J., Chen, W., Fan, X., Pan, H., Yao, X., Ren, T.,

Wetting dosing system DS (2020). Available at http://kezsb.ru/produkciya/seriynaya-produkciya/sredstvapylepodavleniya/dozator-zhidkogo-smachivatelya-ds/

Xia, Y. Liu, J., Shi, T., Xiang, H. and Bi, Y. (2014). Prevalence of pneumoconiosis in Hubei, China from 2008 to 2013. Int J Environ Res Public Health, 11 (9), 8612-8621, https://doi.org/10.3390/ijerph110908612

Zhikharev, S.Ya., Rodionov, V.A. and Pihkonen, L.V. (2018). Innovative methods for investigating technological properties and explosion/fire risk data of coal dust. Ghornyi Zhurnal, 6, 45-49. https://doi.org/10.17580/gzh.2018.06.09

Zhmaev, V. V. and Kuznecov, A. L. (2019). Dust suppressor for fine particles. Russia, Pat. no. 2690925. 